\title{
What Does the Arctic's Unstable Past Say about a Sustainable Future?
}

\author{
Henry P. Huntington
}

Ocean Conservancy, Eagle River, AK 99577, USA; hhuntington@oceanconservancy.org

\begin{abstract}
Visions for tomorrow's Arctic include complementary and conflicting ideas such as sustainability, security, prosperity, biodiversity, Indigenous rights, and more. Implicit in many of these views is the assumption that the right combination of policy and action will create a stable configuration producing the intended outcome for the foreseeable future. Even a cursory review of Arctic history, however, shows that economic, political, cultural, ecological, climatic, and other forms of stability are unlikely. Instead, the lessons of the past suggest that local and global factors will continue to interact to create high variability. Individual policies and institutions may help promote effective responses to that variability, but a commitment to enduring equity is necessary to foster long-term well-being for the Arctic and its peoples.
\end{abstract}

Keywords: arctic; sustainability; Indigenous peoples; history; economy

Citation: Huntington, H.P. What Does the Arctic's Unstable Past Say about a Sustainable Future? Sustainability 2021, 13, 8067. https: / / doi.org/10.3390/ su13148067

Academic Editors: Gail Fondahl, Stephanie Pfirman, Grete K. Hovelsrud and Tero Mustonen

Received: 15 May 2021

Accepted: 17 July 2021

Published: 20 July 2021

Publisher's Note: MDPI stays neutral with regard to jurisdictional claims in published maps and institutional affiliations.

Copyright: (C) 2021 by the author. Licensee MDPI, Basel, Switzerland. This article is an open access article distributed under the terms and conditions of the Creative Commons Attribution (CC BY) license (https:/ / creativecommons.org/licenses/by/ $4.0 /)$.

\section{Introduction}

Sustainability is held up as a worthy and indeed necessary goal globally [1] and in the Arctic [2]. The basic idea is to live without squandering our geological, ecological, and societal reserves. The alternative is, of course, to continue to exceed the limits of what the planet can produce and replenish [3], leading eventually to gradual or catastrophic decline of human and ecosystem well-being. In this context, today's decisions about the Arctic will determine the range of tomorrow's possibilities, and the degree to which the Arctic can contribute to a sustainable global future.

A sustainable future is often envisioned as one in which poverty, inequity, and other forms of environmental and social insecurity are reduced or eliminated [1]. Implicit in this vision is a degree of stability that reduces the risk of upheavals and disruptions that can cause widespread economic hardship and spur mass migrations [4]. In considering what the Arctic's future could be, a review of history can help calibrate expectations in the range of the plausible rather than the utopian.

In this essay, I explore the history of human activity in the Arctic, focusing on livelihoods and economics while recognizing that cultural, spiritual, political, technological, environmental, and other factors matter as well. I write as an American scientist of European descent who has worked in the Arctic for all of my professional career. I cannot and do not claim to speak from an Arctic, much less an Arctic Indigenous, perspective.

The past is not a perfect analogue for the future, and I do not suggest that swings between prosperity and hardship are inevitable. Rather, an understanding of the past can help identify what contributes to, and what undermines, stability as seen from different perspectives [5]. Even in a time of rapid climate change [6], the Arctic will continue to exist in one form or another, though that form may be vastly different from the Arctic of today. But humans will still make decisions about the region, and those decisions will affect what happens to Arctic ecosystems and cultures. An ice-free Arctic could still be a relatively productive area with cultures that have adapted to new conditions, or it could be an industrial or military disaster area. What humans have done elsewhere in the world and in the Arctic to date provide insights into the consequences of the choices that may be 
made. The lessons of history may be useful in shaping the future of the Arctic, if Arctic and global societies are willing to heed them.

\section{Early Human Presence in the Arctic}

Humans have lived in the Arctic for tens of thousands of years [7]. Archeologists have identified several major periods and geographies defined by the lands and waters used, the tools developed, and the species hunted, fished, and gathered [8]. This record includes examples of remarkable continuity, such as the continuous occupancy of Point Hope, Alaska, for thousands of years [9]. The record also includes evidence of great disruption, such as the early settlement and then abandonment of Greenland prior to the Common Era [7], as well as many smaller-scale examples of hardship [5,10].

To varying degrees, the early peoples of the Arctic were self-reliant [11]. Trade provided the relatively few materials not available locally [12]. Their lives and livelihoods to some degree met modern definitions of sustainability, but far below today's expectations for material comfort and life expectancy. Environmental variability caused instability at small and large scales, creating a much greater risk of hardship and premature death than would be acceptable to most people now. Many of the early peoples doubtless found their lives satisfying and meaningful, and their deep-rooted respect for nature continues in Indigenous worldviews [13] and offers much in the way of values and experience to guide the future [14], but their material ways of life are not a particularly useful model for tomorrow's Arctic.

\section{Contact and Colonization}

Trade goods, traders, and explorers gradually made their way to the Arctic. Early interactions through the second millennium of the Common Era were likely an extension of existing trade routes and forms of contact. Territorial expansion also played a role, for example in the Norse colonization of Greenland and subsequent, if temporary, expansion into what is now Canada [15]. Arctic peoples themselves were hardly stationary, either. As one example, the Thule Culture of modern-day Inuit expanded rapidly from the Bering Strait region across Arctic North America to Greenland in the first half of the second millennium [16]. At smaller scales, too, migration, resettlement, and assimilation took place, for instance in the 19th century absorption of Koyukon Athabascan peoples in the upper Kobuk River Valley of Alaska into Iñupiaq ways of life and language [17].

Nonetheless, the influence and then visits and then settlements from southern lands brought about lasting change throughout the Arctic. A market for trade goods, including furs and ivory, led to the expansion of trade routes in both volume and geographical extent [18]. In Tsarist Russia, the expansion of empire also included a demand for tribute from remote peoples, typically in the form of furs and other local products [19]. Initially, such trade provided an outlet for surplus production of traditional goods. As demand and thus profits increased, however, traders became more directly involved, establishing annual trade fairs and permanent trading posts [18].

The quest for whale oil and baleen brought new waves of trade and newcomers to the Arctic [20,21]. Whaling crews typically did their own hunting and were also willing to trade with Indigenous communities. Their trade, however, was simply an opportunistic addition to their quest for whales, and the whalers thus had little stake in the long-term well-being of Arctic communities, in at least partial contrast to those who established more permanent trading posts [18].

Whaling at first was carried out from ships that came and left. Later, the whalers established shore-based stations in the Arctic, creating opportunities for Indigenous whalers to join in the commercial hunt, or at least the commercial sale of whale products [21]. The demand for whale products, however, was not sustainable, given the history of reducing and even eradicating whale populations around the world. The commercial bowhead whaling era in the Arctic was no different, with whale populations reduced to a fraction of 
their original size [22]. Whaling ended not because of concerns about sustainability, but because the market for whale products collapsed when alternatives were developed [21].

The trade goods reaching the Arctic through the fur and whale trades, including metal products, were highly sought after, and presumably helped increase material quality of life, even if at least some of the commercial harvests were unsustainable [21]. But beneficial goods were not the only introductions. Alcohol and diseases also came north [18], causing social disruption and death. Arctic peoples switched from living largely independently to many working as producers of raw materials for a global economy, disrupting traditional patterns and norms, and creating, among other things, economic inequality [23]. The Arctic fox boom in the early 20th century is one example, creating a network of trading posts, which exploited trappers to varying degrees [24], and led to families dispersing from communities across the landscape to find their own trapping grounds.

Trade in animal products produced locally was in theory sustainable and provided Arctic residents with opportunities to earn cash and trade goods. The introductions of alcohol and disease were perhaps not inevitable, but were still an all-too-predictable corollary to trade and settlement. In practice, whaling and trapping were not always carried out sustainably, to the detriment of many Arctic communities. St. Lawrence Island, in the northern Bering Sea, is one of the more extreme examples [21]. Whalers decimated the region's walrus population for ivory to supplement their profits, leaving the islanders with fewer sources of food. Alcohol and disease added to the disruption, leading to starvation in the late 1870s, after which only one of the island's communities remained.

In addition to the perils of unsustainable harvest and cultural disruption, the era of furs and whales also demonstrates the risks of dependence on global commodities markets. Bowhead whaling was profitable until baleen was no longer valuable. Arctic fox furs were highly desirable until fashions changed. Even if the take of animals had been ecologically sustainable, there was no guarantee of a lasting economic foundation. The Arctic economy was at the mercy of distant market forces, on which the Arctic had little or no influence. Colonization further eroded local control by imposing the rules and structures of distant governments on Arctic communities.

\section{Post-World War II}

By the mid-20th century, the whaling and trapping economies had disappeared or become too small to provide livelihoods for many people. Around the Arctic, national governments were taking a larger role, bringing cash, jobs, and social services into remote communities [25], which provided inroads for further social, economic, and educational assimilation [26] accompanied by cultural disruption. The Cold War led to the construction of radar and other remote installations, which provided employment [27] for those willing to adhere to the schedules of the wage economy. Even if much food was still produced locally, government support and subsidies were becoming ever more important.

The development of mineral and petroleum resources also increased rapidly. The Gold Rush in the Yukon and Alaska starting in the late 1800s was an unusual frenzy in some ways, and in other ways a precursor of what was to come. Oil had been produced starting in the 1920s in Norman Wells, along Canada's Mackenzie River in the Northwest Territories [28], and geologists had prospected oil seeps on Alaska's North Slope since at least the 1910s [29]. Svalbard's coal reserves were being mined by Norwegians and Soviets [30]. The Arctic was again seen as a land of extractive opportunity, drawing people north in various ways, though rarely with much thought about the well-being of, and often at great cost to, those already living there.

The growth of extractive industrial activities has inevitably led to conflicts with environmental sustainability, at least at local scales. Roads may interfere with migrations of caribou and reindeer [31]. Shipping and offshore oil and gas activities can disrupt marine mammal migrations and Indigenous hunting [32]. Transport of liquid natural gas from Russia's Yamal Peninsula and iron ore from Canada's Baffin Island now take place year-round [33], requiring ice-breaking vessels that create another form of disruption for 
hunters and marine mammals [34]. China's interest in the "Polar Silk Road" is but one indicator of expanding international interest in the Arctic [35]. None of these is necessarily unsustainable, but each activity threatens another incremental reduction in ecological health and productivity. Cumulatively, the course is all too well known from other parts of the world, as lowered expectations for what constitutes a healthy and productive ecosystem lead to altered local cultures and impoverished ecosystems [36].

Commercial fisheries, too, expanded northwards [37]. Salmon fisheries had played a major role in Alaska's bid to become a state, as it sought more control over management of fishes and fishing [38]. Demand for fish products and the technology to catch and process fish combined to make possible massive fisheries in the North Atlantic and North Pacific [39]. By the late 20th century, shrimp were a major source of Greenland's export earnings [37], and the Barents and Bering Seas fisheries were both lucrative and widely regarded as well managed [39].

While fisheries may seem a strong candidate for the foundation of a sustainable economy, they too depend on global markets and on continued willingness to accept management restrictions today to protect tomorrow's fish catches. Competition from salmon farming has greatly reduced the price for wild-caught salmon [40]. Climate change and ocean acidification may reduce the stocks of commercially valuable fish [41]. Conflicts about the allocation of fish catches or the role of by-catch may also disrupt support for current fisheries' management approaches [42]. If fisheries expand still farther north, new conflicts may arise domestically and internationally [43].

Politically, recent decades have seen expanded recognition of Indigenous rights, including land and resource ownership and access rights, creation of Indigenous corporations intended to create economic opportunity, and devolution of some powers to new and existing local and regional governments [44]. These developments are far from uniform across the Arctic, with most activity seen in North America and Greenland. Whether the creation of corporations and government structures is progress toward renewed levels of autonomy or a new form of assimilation is another question [45].

Today's Arctic may seem in some ways a reasonable balance of resource extraction, traditional cultures, fisheries, government support, and other economic pillars. On the other hand, today's Arctic is the product of happenstance, countless small decisions taken separately that together have created the various systems found in different countries. These systems each have their strengths and their weaknesses, but none provides a reliable basis for a stable and sustainable economy and society. Some major financial companies are reducing their investments in fossil fuels, which could reduce new Arctic oil and gas production in some regions such as Alaska [46]. Climate change is disrupting ecosystems, threatening fisheries [41] and causing more and more wildfires [6]. Arctic communities increasingly depend on government spending, including subsidies [47], but budgetary strain may undermine continued political willingness to support those expenditures. Today's decisions will shape tomorrow's Arctic, but where and how are those decisions being made?

\section{The Future}

Arctic regions have long aspired to create viable economies. They have also aspired to political control, up to and including independence [48]. Political independence is incompatible with economic dependence, and so economic development is often seen as a necessary ingredient in self-determination. Coupled with a desire to reduce the relative poverty common around the Arctic [47], there is thus a strong incentive to develop now and to worry about sustainability later.

In different regions at different times, the Arctic has enjoyed periods of economic prosperity. Not since before contact and colonization, however, has the Arctic enjoyed economic and political independence in the sense of having the ability to control its own destiny. To the contrary, the modern Arctic economy is primarily a reaction to global market demands and the willingness of southern governments to spend money in the North. 
Then again, few if any countries anywhere have enjoyed a stable economy over the past century, if "stable" means an economy that has followed the same basic pathway without interruption. Economies change and evolve, and stability is achieved by diversity and innovation rather than by stasis. One can look at the history of the Arctic as one of flexibility, taking advantage of the opportunities of the moment rather than chasing an impossible dream of stable economic self-determination. Flexibility comes at a price, however, including periods of hardship as booms give way to busts. A long-term outlook could help counterbalance the appeal of the quick payoff and support investments that promote economic diversification and a greater degree of self-sufficiency.

If Arctic history suggests instability is the norm, then perhaps shaping tomorrow's Arctic should be reframed as creating the conditions that will allow tomorrow's Arctic the greatest scope for shaping itself. This idea is compatible with the concept of sustainability, insofar as today's choices should not limit the choices available tomorrow [49]. Resources used or damaged today are not available tomorrow, and thus society should be cautious in its choices and actions. At the same time, the more rigid the institutional and other arrangements that are made today, the scope of choices available tomorrow will be smaller, and adjustments will be harder to make.

Today there are competing visions for the Arctic [50], ranging from resource storehouse to Indigenous homeland to geostrategic theater and beyond. As long as the Arctic is sparsely populated and subject to modest levels of human activity, these visions can coexist to at least some degree. That possibility is unlikely to last. Sooner or later, those with an interest in the Arctic will have to determine who should make choices, and those making the choices will have to decide which pathways to follow and which to abandon. The current path is one of incremental and reactive compromise, which leads not to sustainability, but to an inevitable decline.

An alternative path is to focus on basic principles, specifically a commitment to living equitably within the social and ecological bounds of the Arctic, from which specific policies and actions can be developed and adjusted as needed. The Arctic today is still the home of intact ecosystems and vibrant cultures not through carefully planning, but because it lies at the margins of the human presence on Earth. Geographical chance will not suffice to protect the Arctic of tomorrow. An economy of reaction will not create a sustainable Arctic tomorrow. Decisions made elsewhere for other reasons will turn Arctic well-being into collateral damage as external ambitions take precedence. The only pathway to a sustainable Arctic future is to commit to the long-term well-being of Arctic cultures, landscapes, and waters as a priority, with other interests to follow only insofar as they are compatible with Arctic well-being.

Funding: This research received no external funding.

Conflicts of Interest: The author declares no conflict of interest.

\section{References}

1. United Nations. Sustainable Development Goals Report; United Nations Publications: New York, NY, USA, 2019.

2. Petrov, A.N.; Vlasova, T. Towards an Arctic sustainability monitoring framework. Sustainability 2021, 13, 4800. [CrossRef]

3. Rockström, J.; Steffen, W.; Noone, K.; Persson, Å.; Chapin, F.S.; Lambin, E.F.; Lenton, T.M.; Scheffer, M.; Folke, C.; Schellnhuber, H.J.; et al. A safe operating space for humanity. Nature 2009, 461, 472-475. [CrossRef] [PubMed]

4. Oliver-Smith, A.; Shen, X. (Eds.) Linking Environmental Change, Migration and Social Vulnerability; UNU Institute for Environment and Human Security: Bonn, Germany, 2009.

5. Krupnik, I.; Crowell, A.L. (Eds.) Arctic Crashes; Smithsonian Scholarly Press: Washington, DC, USA, 2020.

6. Thoman, R.L.; Richter-Menge, J.; Druckenmiller, M.L. (Eds.) Arctic Report Card 2020; National Oceanic and Atmospheric Administration: Silver Spring, MD, USA, 2020.

7. Pitulko, V.V.; Tikhonov, A.N.; Pavlova, E.Y.; Nikolskiy, P.A.; Kuper, K.E.; Polozov, R.N. Early human presence in the Arctic: Evidence from 45,000-year-old mammoth remains. Science 2016, 351, 260-263. [CrossRef] [PubMed]

8. Friesen, T.M.; Mason, O.K. (Eds.) The Oxford Handbook of the Prehistoric Arctic; Oxford University Press: Oxford, UK, 2016.

9. Rainey, F.G. Whale hunters of Tigara. Am. Mus. Nat. Hist. 1947, 41, 231-283. 
10. Mason, O.K.; Gerlach, S.C. Chukchi hot spots, paleo-polynyas, and caribou crashes: Climatic and ecological dimensions of North Alaska prehistory. Arct. Anthropol. 1995, 32, 101-130.

11. Krupnik, I. Arctic Adaptations: Native Whalers and Reindeer Herders of Northern Eurasia; University Press of New England: Hanover, NH, USA, 1993.

12. Fitzhugh, W.W.; Crowell, A. Crossroads of Continents; Smithsonian: Washington, DC, USA, 1988.

13. Petersen, H.C. Kalaalit Ilisimasaat/Local Knowledge; IPI Press: Hanover, NH, USA, 2010.

14. Zdor, E.; Huntington, H.P. Tradition connects the past, present, and future of the Arctic Ocean. In Whither the Arctic Ocean? Wassmann, P., Ed.; BBVA Foundation: Bilbao, Spain, 2021; pp. 195-203.

15. Thorsson, Ö. (Ed.) Sagas of the Icelanders; Penguin: New York, NY, USA, 2000.

16. McGhee, R. The Last Imaginary Place: A Human History of the Arctic World; Oxford University Press: Oxford, UK, 2005.

17. Burch, E.S., Jr. The Iñupiaq Nations of Northwest Alaska; University of Alaska Press: Fairbanks, AK, USA, 1998.

18. Bockstoce, J.R. Fur and Frontiers in the Far North; Yale University Press: New Haven, CT, USA, 2010.

19. Slezkine, Y. Arctic Mirrors; Cornell University Press: Ithaca, NY, USA, 1994.

20. Ross, W.G. Arctic Whalers, Icy Seas: Narratives of the Davis Strait Whale Fishery; Irwin: Toronto, ON, Canada, 1985.

21. Bockstoce, J.R. Whales, Ice E Men; University of Washington: Seattle, DC, USA, 1986.

22. Givens, G.H.; Heide-Jørgensen, M.P. Abundance. In The Bowhead Whale; George, J.C., Thewissen, J.G.M., Eds.; Academic Press: London, UK, 2020; pp. 77-86.

23. Blackman, M.B. Sadie Brower Neakok: An Iñupiaq Woman; University of Washington: Seattle, DC, USA, 1989.

24. Bockstoce, J.R. White Fox and Icy Seas in the Western Arctic; Yale University Press: New Haven, CT, USA, 2018.

25. Spencer, R.F. The North Alaskan Eskimo: A Study in Ecology and Society; U.S. Government Printing Office: Washington, DC, USA, 1959.

26. Okakok, L. Serving the purpose of education. Harv. Educ. Rev. 1989, 59, 405-422. [CrossRef]

27. Chasen, R.E. Distant early warning systems in the North American Arctic. Polar Rec. 1967, 13, 595-596. [CrossRef]

28. AMAP. Assessment 2007: Oil and Gas Activities in the Arctic-Effects and Potential Effects; Arctic Monitoring and Assessment Programme: Oslo, Norway, 2010.

29. de Leffingwell, E.K. The Canning River Region, Alaska; Government Printing Office: Washington, DC, USA, 1919.

30. Arlov, T. Svalbards Historie; Tapir: Trondheim, Norway, 2003. (In Norwegian)

31. Wilson, R.; Parrett, L.; Joly, K.; Dau, J. Effects of roads on individual caribou movements during migration. Biol. Conserv. 2016, 195, 2-8. [CrossRef]

32. Huntington, H.P.; Daniel, R.; Hartsig, A.; Harun, K.; Heiman, M.; Meehan, R.; Noongwook, G.; Pearson, L.; Prior-Parks, M.; Robards, M. Vessels, risks, and rules: Planning for safe shipping in Bering Strait. Mar. Policy 2015, 51, 119-127. [CrossRef]

33. Vetter, D. Russian Gas Tanker's Arctic Ice Voyage Branded “Irony of Our Time." Forbes, 24 February 2021. Available online: https:/ / www.forbes.com/sites/davidrvetter/2021/02/24/russian-gas-tankers-arctic-ice-voyage-branded-irony-of-our-time (accessed on 19 July 2021).

34. Erbe, C.; Marley, S.; Schoeman, R.; Smith, J.; Trigg, L.; Embling, C. The effects of ship noise on marine mammals-A review. Front. Mar. Sci. 2019, 6, 606. [CrossRef]

35. Su, P.; Huntington, H.P. Using critical geopolitical discourse to examine China's engagement in Arctic affairs. Territ. Politics Gov. 2021. [CrossRef]

36. Pauly, D. Anecdotes and the shifting baseline syndrome of fisheries. Trends Ecol. Evol. 1995, 10, 430. [CrossRef]

37. Hamilton, L.C.; Brown, B.C.; Rasmussen, R.O. West Greenland's cod-to-shrimp transition: Local dimensions of climatic change. Arctic 2003, 56, 271-282. [CrossRef]

38. Mackovjak, J. Alaska's Salmon Traps; Cross Sound Innovations: Gustavus, AK, USA, 2013.

39. Vilhjalmsson, H.; Hoel, A.H. Fisheries and aquaculture. In Arctic Climate Impact Assessment; Cambridge University Press: Cambridge, UK, 2005; pp. 691-780.

40. Knapp, G.; Roheim, C.; Anderson, J. The Great Salmon Run: Competition between Wild and Farmed Salmon; Traffic North America: Washington, DC, USA, 2007.

41. AMAP. AMAP Assessment 2018: Arctic Ocean Acidification; Arctic Monitoring and Assessment Programme: Tromsø, Norway, 2018.

42. Smiley, S. Commercial and Subsistence Harvesters Speak out against Trawler Bycatch of Chinook Salmon; KSTK: Wrangell, AK, USA, 2021.

43. Zou, L.; Huntington, H.P. Implications of the Convention on the Conservation and Management of Pollock Resources in the Central Bering Sea for the management of fisheries in the central Arctic Ocean. Mar. Policy 2017, 88, 132-138. [CrossRef]

44. Loukacheva, N. The Arctic Promise: Legal and Political Autonomy of Greenland and Nunavut; University of Toronto Press: Toronto, ON, Canada, 2007.

45. Mitchell, D.C. Sold American: The Story of Alaska Natives and Their Land, 1867-1959; University of Alaska Press: Fairbanks, AK, USA, 2003.

46. Herz, N. Anxiety Creeps into Oil-Dependent Alaska as Banks Step back from Arctic Investment; Alaska Public Media: Anchorage, AK, USA, 2020.

47. Glomsrød, S.; Duhaime, G.; Aslaksen, I. The Economy of the North 2015; Statistics Norway: Oslo, Norway, 2017. 
48. Olsen, I.H. Greenland, the Arctic, and the issue of representation: What is the Arctic? Who has a Say? In The Arctic and World Order; Spohr, K., Hamilton, D.S., Eds.; Johns Hopkins School of Advanced International Studies: Washington, DC, USA, 2020; pp. 77-95.

49. World Commission on Environment and Development. Our Common Future; Oxford University Press: Oxford, UK, 1987.

50. Young, O. Shifting ground: Competing policy narratives and the future of the Arctic. In The Arctic and World Order; Spohr, K., Hamilton, D.S., Eds.; Johns Hopkins School of Advanced International Studies: Washington, DC, USA, 2020; pp. 47-62. 